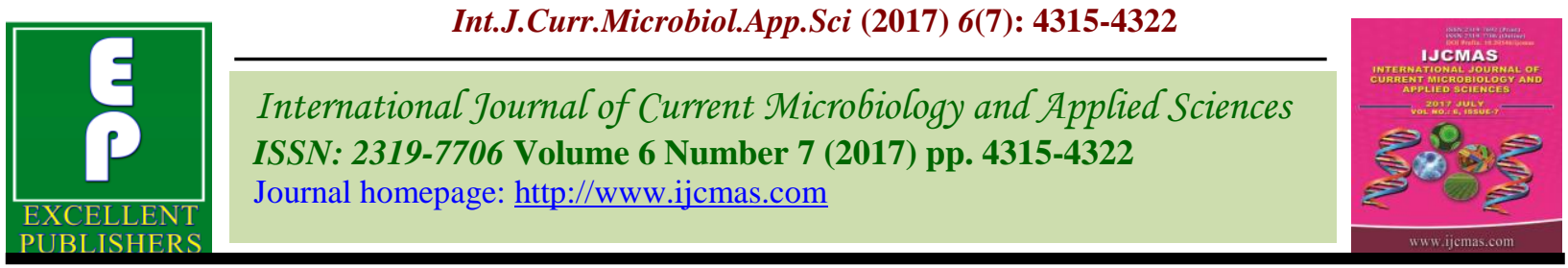

Original Research Article

https://doi.org/10.20546/ijcmas.2017.607.449

\title{
Growth and Yield of Kharif Sown Sunflower as Influenced by Plant Density and Nutrient Management
}

\author{
S. Ravichandran* and K. Srinivasan \\ Department of Agronomy, Tamil Nadu Agricultural University, Coimbatore-641003, India \\ *Corresponding author
}

A B S T R A C T

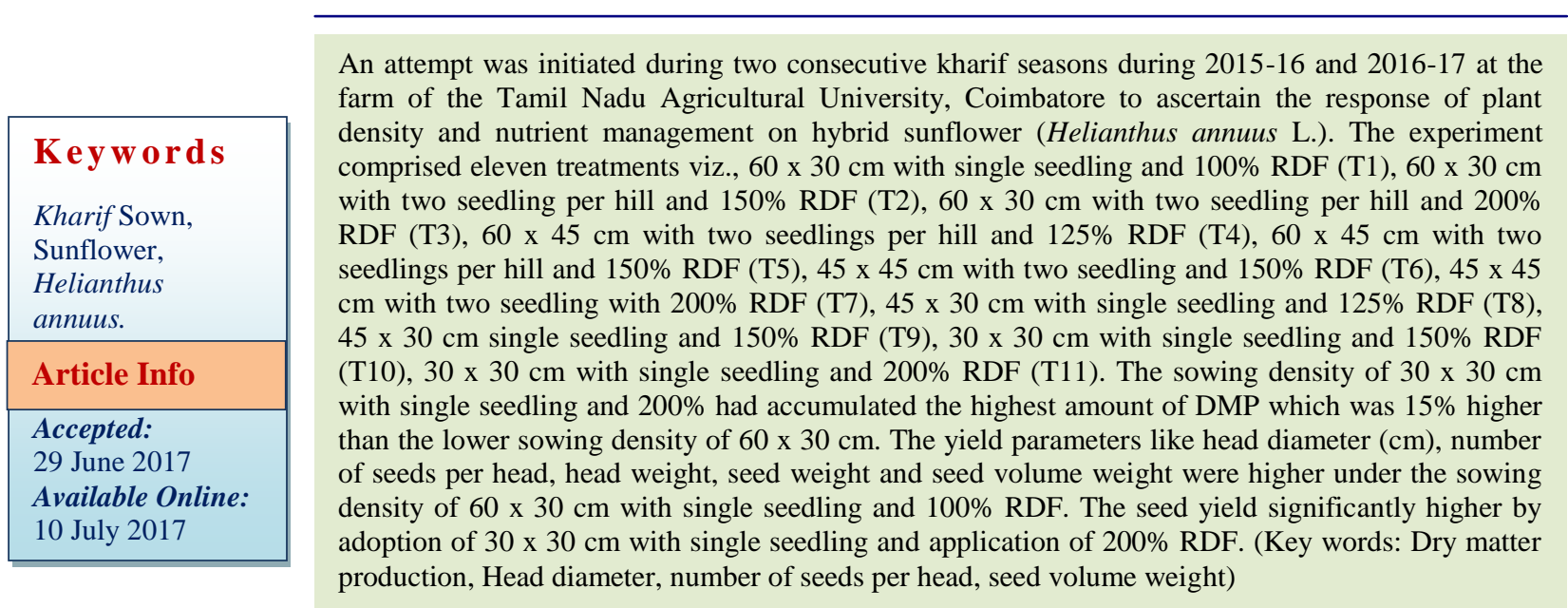

\section{Introduction}

Oil seeds play an important role in Indian agriculture as food and an industrial commodity. India is the largest producer of oilseeds in the world in terms of output and in terms of area (Rasool et al., 2013). Among the oilseed crops, sunflower (Helianthus annuus L.) is an all-season crop. It is a crop with short duration and photo-insensitivity, suits well to rainy season (Thimmegowda et al., 2007). Sunflower because of its quantity and quality of edible oil occupies an important position in the world among the new oil seed crops. Its ranked fourth among all oilseed crops of the world (Petcu et al., 2010). It is the most important oilseed crop due to its wide adaptability and very high seed oil content ranging from 40 to 50 per cent, no cholesterol and high non saturated fatty acids content that ranged between 85$91 \%$. Plant spacing effects are greatly prominent in various crops including sunflower because there is no option of filling gaps between plants by tillering and branching. Thus an appropriate plant stand may help in harnessing the entire renewable resources in a supplementary and proficient approach toward high crop yields. The increasing plant population in field incremental and negative effects were recorded on plant height and head diameter, 
respectively (Mojiri and Arzani, 2003). Seed yield was increased up to a plant population of 85000 plants $\mathrm{ha}^{-1}$ while beyond this had a depressing outcome on production. Higher plant density produce taller plants, lighter seeds and more yield than low plant population (Beg et al., 2003; Ullasa et al., (2014). Nitrogen is a structural component of amino acids, protein and chlorophyll. Phosphorus is a constituent of ATP, ADP, nucleic acids and phospholipids. Potassium is involved in providing appropriate ionic environment for metabolic process, growth regulation, stomatal control, activation of enzymes and photosynthesis. Judicious application of $\mathrm{N}, \mathrm{P}$ and $\mathrm{K}$ nutrient enhances the crop growth and development which helps in increasing seed yield, oil content. The greatest limitation for increasing the productivity of this crop is inadequate supply of nutrients and maintenance of optimum plant population. In view of above the present investigation was carried out to study the effect of plant density and nutrient management on growth and yield of sunflower.

\section{Materials and Methods}

A field experiments were conducted at Tamil Nadu Agricultural university, Coimbatore during Kharif season of 2015-16 and 2016-17 to investigate the effect of planting density and nutrient management on growth, yield and quality of sunflower. The experimental site is geographically situated in the western agro-climatic zone of Tamil Nadu at $11^{\circ} \mathrm{N}$ latitude and $77^{\circ} \mathrm{E}$ longitude and at an altitude of 426.7 meters above mean sea level (MSL). The study was conducted in randomized block design and replicated thrice. The treatment comprised of $60 \times 30 \mathrm{~cm}$ with single seedling and $100 \%$ RDF $\left(\mathrm{T}_{1}\right), 60 \times 30 \mathrm{~cm}$ with two seedling per hill and $150 \% \operatorname{RDF}\left(\mathrm{T}_{2}\right)$, $60 \times 30 \mathrm{~cm}$ with two seedling per hill and $200 \%$ RDF $\left(\mathrm{T}_{3}\right), 60 \times 45 \mathrm{~cm}$ with two seedlings per hill and $125 \% \operatorname{RDF}\left(\mathrm{T}_{4}\right), 60 \times 45$ $\mathrm{cm}$ with two seedlings per hill and $150 \%$ RDF $\left(\mathrm{T}_{5}\right), 45 \mathrm{x} 45 \mathrm{~cm}$ with two seedling and $150 \%$ RDF $\left(\mathrm{T}_{6}\right), 45 \times 45 \mathrm{~cm}$ with two seedling with $200 \% \operatorname{RDF}\left(\mathrm{T}_{7}\right), 45 \times 30 \mathrm{~cm}$ with single seedling and $125 \% \operatorname{RDF}\left(\mathrm{T}_{8}\right), 45 \times 30 \mathrm{~cm}$ single seedling and $150 \%$ RDF ( $\left.\mathrm{T}_{9}\right), 30 \times 30$ $\mathrm{cm}$ with single seedling and $150 \% \operatorname{RDF}\left(\mathrm{T}_{10}\right)$, $30 \times 30 \mathrm{~cm}$ with single seedling and $200 \%$ RDF $\left(\mathrm{T}_{11}\right)$. The soil of the experimental field was sandy clay loam in texture belonging to TypicUstropept. The nutrient status of the soil during start of the experiment was low in available nitrogen, medium in available phosphorus and high in available potassium. The field experiments were conducted during kharif (June - September) season of 2015 and 2016. The sunflower hybrid, TNAU Sunflower Hybrid $\mathrm{CO} 2$ was used as test crop. The recommended fertilizer dose followed for sunflower was 90:60:60 $\mathrm{kgNPK} \mathrm{ha}{ }^{-1}$. Half dose of $\mathrm{N}$ and $\mathrm{K}$ and full dose of $\mathrm{P}$ were applied basally to all the treatments. The remaining $\mathrm{N}$ and $\mathrm{K}$ were top dressed at 30 DAS. The crop was harvested at maturity stage, seed yield per net plot of each treatment was recorded. Five plants were selected in each net plotarea for measuring nutrients uptake. The various biometric observations on 90 DAS, analytical data of plant sample and the computed data were subjected to statistical scrutiny as per the procedures given by (Gomezand Gomez, 1984). The treatment differences were worked out at five per cent probability level.

\section{Results and Discussion}

\section{Growth parameters (Table 1)}

Dry matter production (DMP) of sunflower plants at the harvest stage significantly influenced by plant density and nutrient management levels. Spacing of $30 \times 30 \mathrm{~cm}$ with single seedling and $200 \%\left(\mathrm{~T}_{11}\right)$ was accumulated the highest amount of DMP $(6938 \mathrm{~kg} / \mathrm{ha})$ which was $15 \%$ higher than the lower plant density of $60 \times 30 \mathrm{~cm}$. The data 
suggest that the highest DMP recorded at the optimal planting geometry may be as a consequence of large canopy spread area and leaf area index. Effective utilization of natural resources such as water, soil nutrients and solar radiation would have supported the plants to gain greater net assimilation rate and produced higher DMP in $30 \times 30 \mathrm{~cm}$ with single seedling and $200 \%\left(\mathrm{~T}_{11}\right)$. The results are in conformity with the findings of Singh and Pacheria (1981).

At 90 DAS significant influence on number of leaves per hill was observed during kharif and rabi season of 2015-16 and 2016-17. The treatment $60 \times 30 \mathrm{~cm}$ with two seedlings per hill and application of $200 \%$ RDF significantly recorded 42.8 and 43.1 leaves per hill during kharif2015-16andkharif201617 respectively. This may be due to the two plants accommodated in a hill in the treatment resulted in higher number of leaves.

At harvest, $\mathrm{T}_{1}(60 \mathrm{x} 30 \mathrm{~cm}$ with single seedling and $100 \%$ RDF) significantly recorded higher stem girth of $3.90 \mathrm{~cm}$ and $4.17 \mathrm{~cm}$ during kharif 2015-16 and 2016-17 respectively. This was due to less competition between the plants which leads to the better utilization of available resources viz., light, moisture and nutrients at optimum plant population. The lower stem girth was recorded at closer spacing due to the high competition between the plants for nutrient, moisture and light. These results are in concurrence with those of Vijayakumar and Ramesh (Vijayakumar and Ramesh, 2005). The root volume (68.3 and 74.3) and root dry weight (58.7 and $59.3 \mathrm{~g}$ ) was higher under the $60 \times 30 \mathrm{~cm}$ with single seedling and $100 \%$ RDF.

\section{Growth analysis (Table 2)}

The plant population favourably influenced the LAI and the high plant population $\left(\mathrm{T}_{4}\right)$ registered the higher LAI at all the stages.
LAI of 16.37 and 16.55 during kharif 2015 and 2016 was recorded under $\mathrm{T}_{4}$. Significant influence on CGR and RGR was observed during the course of investigation. The highest CGR and RGR value was recorded in $\mathrm{T}_{11} 30 \times 30 \mathrm{~cm}$ with single seedling and $200 \%$. This may be due to the higher number of leaves per hill and higher leaf area per hill which reflected on the higher value of LAI. Moreover, wider space availability between the rows and optimum intra row spacing might have increased the root spread which eventually utilized the applied nutrients and water effectively, which reflected on higher leaf area and more number of leaves per hill and was due to the lesser value of spacing $\left(900 \mathrm{~cm}^{2}\right)$ in numerator might have increased the CGR and RGR of the treatment.

Yield parameters and seed yield (Table 3 and 4)

During kharif season of 2015-16 and 2016-17, the $\mathrm{T}_{1}(60 \times 30 \mathrm{~cm}$ with single seedling and application of $100 \%$ RDF) recorded higher head diameter $(33.1 \mathrm{~cm}$ and $32.4 \mathrm{~cm}$ respectively) as against the lower head diameter $(16.5 \mathrm{~cm}$ and $17.5 \mathrm{~cm}$ respectively) recorded in $45 \times 45 \mathrm{~cm}$ with two seedling per hill and application of $150 \%$ RDF $\left(\mathrm{T}_{6}\right)$. The same treatment registered higher number of seeds per head, 100 seed weight and seed volume weight.

This may be ascribed to the overall improvement in crop vigour and production of sufficient photosynthates owing to higher availability of nutrients (Ashwathi et al., 1991). The sowing density and different nutrient levels had exerted a significant positive influence on seed yield of sunflower. Sunflower grown at $30 \times 30 \mathrm{~cm}$ with single seedling and $200 \%$ RDF $\left(\mathrm{T}_{11}\right)$ produced higher seed yield (2992 and $3232 \mathrm{~kg} \mathrm{ha}^{-1}$ ) over $60 \times 30 \mathrm{~cm}$ with single seedling and $100 \%$ $\operatorname{RDF}\left(\mathrm{T}_{1}\right)$. 
Table.1 Effect of planting density and nutrient management on number of leaves per hilland dry matter production (kg ha-1)at 90 DAS of sunflowerduring kharif season

\begin{tabular}{|c|c|c|c|c|c|}
\hline \multirow{2}{*}{\multicolumn{2}{|c|}{ Treatment }} & \multicolumn{2}{|c|}{ No. of leaves per hill } & \multicolumn{2}{|c|}{ DMP (kg ha $\left.{ }^{-1}\right)$} \\
\hline & & 2015-16 & 2016-17 & 2015-16 & 2016-17 \\
\hline $\mathbf{T}_{1}$ & $60 \times 30 \mathrm{~cm}$ with single seedling with $100 \% \mathrm{RDF}$ & 28.1 & 28.3 & 5631 & 6284 \\
\hline $\mathbf{T}_{2}$ & $60 \times 30 \mathrm{~cm}$ with two seedling with $150 \%$ RDF & 42.8 & 41.6 & 8510 & 8954 \\
\hline $\mathbf{T}_{\mathbf{3}}$ & $60 \times 30 \mathrm{~cm}$ with two seedling with $200 \%$ RDF & 45.7 & 46.5 & 9285 & 9805 \\
\hline $\mathbf{T}_{4}$ & $60 \times 45 \mathrm{~cm}$ with two seedling with $125 \%$ RDF & 37.0 & 37.1 & 6511 & 6897 \\
\hline $\mathbf{T}_{5}$ & $60 \times 45 \mathrm{~cm}$ with two seedling with $150 \%$ RDF & 39.9 & 38.2 & 6535 & 7306 \\
\hline $\mathbf{T}_{6}$ & 45 x $45 \mathrm{~cm}$ with two seedling with $150 \%$ RDF & 34.1 & 32.2 & 7169 & 8502 \\
\hline $\mathbf{T}_{7}$ & $45 \times 45 \mathrm{~cm}$ with two seedling with $200 \%$ RDF & 36.2 & 35.0 & 7432 & 8536 \\
\hline $\mathbf{T}_{8}$ & $45 \times 30 \mathrm{~cm}$ with single seedling with $125 \%$ RDF & 27.0 & 26.5 & 6643 & 7573 \\
\hline $\mathbf{T}_{9}$ & $45 \times 30 \mathrm{~cm}$ with single seedling with $150 \%$ RDF & 27.9 & 27.6 & 6712 & 7876 \\
\hline $\mathbf{T}_{\mathbf{1 0}}$ & $30 \times 30 \mathrm{~cm}$ with single Seedling with $150 \%$ RDF & 24.0 & 22.5 & 10057 & 10652 \\
\hline $\mathbf{T}_{11}$ & $30 \times 30 \mathrm{~cm}$ with single Seedling with $200 \%$ RDF & 25.3 & 26.2 & 10826 & 11524 \\
\hline & 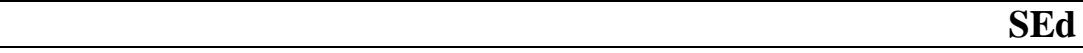 & 1.3 & 1.4 & 411 & 426 \\
\hline & CD (0.05) & 2.8 & 2.9 & 859 & 890 \\
\hline
\end{tabular}

Table.2 Effect of planting density and nutrient management on stem girth (cm), root volume (cc) and root dry weight (g) of sunflower at 90 DAS during kharif season

\begin{tabular}{|c|c|c|c|c|c|c|c|}
\hline \multirow{2}{*}{\multicolumn{2}{|c|}{ Treatment }} & \multicolumn{2}{|c|}{ Stem girth $(\mathrm{cm})$} & \multicolumn{2}{|c|}{ Root volume (cc) } & \multicolumn{2}{|c|}{ Root dry mass (g) } \\
\hline & & 2015-16 & 2016-17 & 2015-16 & 2016-17 & 2015-16 & 2016-17 \\
\hline $\mathbf{T}_{1}$ & $60 \times 30 \mathrm{~cm}$ with single seedling with $100 \%$ RDF & 6.75 & 7.18 & 68.3 & 74.3 & 58.7 & 59.3 \\
\hline $\mathbf{T}_{2}$ & $60 \times 30 \mathrm{~cm}$ with two seedling with $150 \%$ RDF & 4.68 & 4.72 & 39.6 & 43.0 & 24.6 & 26.8 \\
\hline $\mathbf{T}_{3}$ & $60 \times 30 \mathrm{~cm}$ with two seedling with $200 \%$ RDF & 4.97 & 5.02 & 41.1 & 44.7 & 25.2 & 27.4 \\
\hline $\mathbf{T}_{4}$ & $60 \times 45 \mathrm{~cm}$ with two seedling with $125 \%$ RDF & 5.12 & 5.17 & 42.6 & 46.4 & 26.8 & 29.1 \\
\hline $\mathbf{T}_{5}$ & $60 \times 45 \mathrm{~cm}$ with two seedling with $150 \%$ RDF & 5.15 & 5.23 & 45.2 & 49.1 & 26.9 & 29.3 \\
\hline $\mathbf{T}_{6}$ & 45 x $45 \mathrm{~cm}$ with two seedling with $150 \%$ RDF & 4.54 & 4.51 & 30.7 & 33.4 & 19.8 & 21.5 \\
\hline $\mathbf{T}_{7}$ & 45 x $45 \mathrm{~cm}$ with two seedling with $200 \%$ RDF & 4.63 & 4.67 & 32.7 & 35.5 & 22.7 & 24.7 \\
\hline $\mathbf{T}_{\mathbf{8}}$ & 45 x $30 \mathrm{~cm}$ with single seedling with $125 \%$ RDF & 5.72 & 6.12 & 58.0 & 63.2 & 48.5 & 51.1 \\
\hline $\mathbf{T}_{9}$ & $45 \times 30 \mathrm{~cm}$ with single seedling with $150 \%$ RDF & 6.23 & 6.64 & 62.9 & 68.4 & 54.5 & 55.1 \\
\hline $\mathbf{T}_{10}$ & 30 x $30 \mathrm{~cm}$ with single Seedling with $150 \%$ RDF & 5.18 & 5.44 & 49.6 & 52.8 & 39.5 & 43.1 \\
\hline $\mathbf{T}_{11}$ & 30 x $30 \mathrm{~cm}$ with single Seedling with $200 \%$ RDF & 5.20 & 5.56 & 53.3 & 57.9 & 43.5 & 47.1 \\
\hline & SEd & 0.25 & 0.24 & 0.25 & 2.2 & 2.4 & 1.7 \\
\hline & CD (0.05) & 0.52 & 0.51 & 0.51 & 4.6 & 5.1 & 3.6 \\
\hline
\end{tabular}


Table.3 Effect of planting density and nutrient management on growth analytical parameters of sunflower during kharif season

\begin{tabular}{|c|c|c|c|c|c|c|c|}
\hline \multirow{2}{*}{\multicolumn{2}{|c|}{$\begin{array}{c}\text { Treatment } \\
\end{array}$}} & \multicolumn{2}{|c|}{ LAI } & \multicolumn{2}{|c|}{$\begin{array}{c}\text { CGR } \\
\left(\mathrm{g} \mathrm{m}^{-2} \text { day }^{-1}\right)\end{array}$} & \multicolumn{2}{|c|}{$\begin{array}{c}\text { RGR } \\
\left(\mathrm{mg} \mathrm{g}^{-1} \text { day }^{-1}\right)\end{array}$} \\
\hline & & 2015-16 & 2016-17 & 2015-16 & 2016-17 & 2015-16 & 2016-17 \\
\hline $\mathbf{T}_{1}$ & $60 \times 30 \mathrm{~cm}$ with single seedling with $100 \%$ RDF & 6.44 & 6.58 & 2.33 & 2.02 & 2.21 & 2.43 \\
\hline $\mathbf{T}_{2}$ & $60 \times 30 \mathrm{~cm}$ with two seedling with $150 \%$ RDF & 14.26 & 14.44 & 2.51 & 2.75 & 4.25 & 3.69 \\
\hline $\mathbf{T}_{\mathbf{3}}$ & $60 \times 30 \mathrm{~cm}$ with two seedling with $200 \%$ RDF & 16.37 & 16.55 & 2.60 & 3.15 & 4.65 & 5.32 \\
\hline $\mathbf{T}_{4}$ & $60 \times 45 \mathrm{~cm}$ with two seedling with $125 \%$ RDF & 7.18 & 7.46 & 1.45 & 1.64 & 2.23 & 2.45 \\
\hline $\mathbf{T}_{5}$ & $60 \times 45 \mathrm{~cm}$ with two seedling with $150 \%$ RDF & 8.16 & 8.25 & 1.68 & 1.69 & 2.28 & 2.50 \\
\hline $\mathbf{T}_{6}$ & $45 \times 45 \mathrm{~cm}$ with two seedling with $150 \%$ RDF & 7.78 & 7.76 & 1.91 & 1.78 & 2.34 & 2.57 \\
\hline $\mathbf{T}_{7}$ & 45 x 45 cm with two seedling with $200 \%$ RDF & 9.28 & 8.64 & 2.02 & 2.19 & 2.47 & 2.72 \\
\hline $\mathbf{T}_{8}$ & $45 \times 30 \mathrm{~cm}$ with single seedling with $125 \%$ RDF & 7.48 & 7.68 & 2.15 & 2.53 & 2.76 & 3.03 \\
\hline $\mathbf{T}_{9}$ & $45 \times 30 \mathrm{~cm}$ with single seedling with $150 \%$ RDF & 7.96 & 8.72 & 2.42 & 2.54 & 2.95 & 3.24 \\
\hline $\mathbf{T}_{10}$ & $30 \times 30 \mathrm{~cm}$ with single Seedling with $150 \%$ RDF & 6.02 & 6.78 & 2.76 & 3.41 & 5.25 & 5.81 \\
\hline \multirow[t]{3}{*}{$\mathbf{T}_{11}$} & $30 \times 30 \mathrm{~cm}$ with single Seedling with $200 \%$ RDF & 10.16 & 10.20 & 3.38 & 3.74 & 5.68 & 6.24 \\
\hline & SEd & 0.47 & 0.47 & 0.46 & 0.11 & 0.12 & 0.18 \\
\hline & CD (0.05) & 0.99 & 0.98 & 0.97 & 0.23 & 0.25 & 0.37 \\
\hline
\end{tabular}

Table.4 Effect of planting density and nutrient management on yield parameters of sunflower during kharif season

\begin{tabular}{|c|c|c|c|c|c|c|c|c|}
\hline \multirow[b]{2}{*}{ Treatment } & \multicolumn{2}{|c|}{$\begin{array}{c}\text { Head diameter } \\
(\mathrm{cm})\end{array}$} & \multicolumn{2}{|c|}{ No. of seeds head ${ }^{-1}$} & \multicolumn{2}{|c|}{$\begin{array}{l}\text { Head weight } \\
\text { (g) }\end{array}$} & \multicolumn{2}{|c|}{$\begin{array}{c}\text { Seed volume weight } \\
\text { (g) }\end{array}$} \\
\hline & $2015-16$ & 2016-17 & 2015-16 & 2016-17 & $2015-16$ & 2016-17 & $2015-16$ & 2016-17 \\
\hline$T_{1}$ & 33.1 & 32.4 & 1391 & 1356 & 24.3 & 24.9 & 38.5 & 38.4 \\
\hline $\mathbf{T}_{2}$ & 20.9 & 19.5 & 924 & 933 & 15.2 & 15.0 & 28.5 & 28.5 \\
\hline $\mathbf{T}_{3}$ & 21.4 & 21.3 & 941 & 950 & 15.7 & 15.6 & 29.1 & 28.5 \\
\hline $\mathbf{T}_{4}$ & 21.8 & 22.0 & 957 & 966 & 16.3 & 16.2 & 29.1 & 28.7 \\
\hline $\mathbf{T}_{\mathbf{5}}$ & 23.7 & 22.7 & 977 & 986 & 16.8 & 16.8 & 29.5 & 29.2 \\
\hline $\mathbf{T}_{6}$ & 16.5 & 17.5 & 871 & 850 & 13.8 & 14.1 & 26.8 & 24.2 \\
\hline $\mathbf{T}_{7}$ & 18.2 & 19.0 & 891 & 900 & 14.2 & 14.8 & 28.3 & 24.7 \\
\hline $\mathbf{T}_{8}$ & 27.5 & 25.5 & 1194 & 1145 & 21.0 & 21.5 & 33.4 & 32.9 \\
\hline $\mathbf{T}_{9}$ & 30.2 & 28.2 & 1295 & 1250 & 22.7 & 23.1 & 36.1 & 35.7 \\
\hline $\mathbf{T}_{10}$ & 24.8 & 24.2 & 987 & 997 & 18.2 & 18.3 & 30.1 & 29.7 \\
\hline $\mathbf{T}_{11}$ & 26.7 & 25.0 & 1085 & 1038 & 18.5 & 19.9 & 30.3 & 30.2 \\
\hline SEd & 1.1 & 1.2 & 46 & 46 & 0.7 & 0.7 & 1.3 & 1.4 \\
\hline CD (0.05) & 2.3 & 2.4 & 95 & 96 & 1.6 & 1.6 & 2.7 & 2.9 \\
\hline
\end{tabular}


Table.5 Effect of planting density and nutrient management on seed yield (kg ha-1)and nutrient uptake (kg ha-1) of sunflower during kharif season

\begin{tabular}{|c|c|c|c|c|c|c|c|c|}
\hline \multirow[t]{2}{*}{ Treatments } & \multicolumn{2}{|c|}{$\begin{array}{c}\text { Seed yield } \\
\left(\mathrm{kg} \mathrm{ha}^{-1}\right)\end{array}$} & \multicolumn{2}{|c|}{$\begin{array}{c}\text { N Uptake } \\
\left(\mathrm{kg} \mathrm{ha}^{-1}\right)\end{array}$} & \multicolumn{2}{|c|}{$\begin{array}{c}\text { P Uptake } \\
\left(\mathrm{kg} \mathrm{ha}^{-1}\right)\end{array}$} & \multicolumn{2}{|c|}{$\begin{array}{c}\text { K Uptake } \\
\left(\mathrm{kg} \mathrm{ha}^{-1}\right)\end{array}$} \\
\hline & 2015-16 & 2016-17 & 2015-16 & 2016-17 & 2015-16 & 2016-17 & 2015-16 & 2016-17 \\
\hline $\mathbf{T}_{1}$ & 2035 & 2034 & 33.8 & 37.7 & 11.3 & 12.6 & 78 & 88 \\
\hline $\mathbf{T}_{2}$ & 2249 & 2469 & 46.4 & 52.1 & 14.9 & 17.6 & 108 & 126 \\
\hline $\mathbf{T}_{\mathbf{3}}$ & 2489 & 2719 & 51.2 & 57.4 & 16.4 & 19.4 & 119 & 138 \\
\hline $\mathbf{T}_{4}$ & 2041 & 2084 & 39.1 & 41.4 & 13.0 & 13.8 & 91 & 96 \\
\hline $\mathbf{T}_{5}$ & 2050 & 2090 & 39.2 & 43.8 & 13.1 & 14.6 & 91 & 102 \\
\hline $\mathbf{T}_{6}$ & 2062 & 2241 & 39.9 & 45.4 & 13.3 & 15.1 & 93 & 106 \\
\hline $\mathbf{T}_{7}$ & 2084 & 2264 & 40.3 & 47.3 & 13.4 & 15.8 & 94. & 110 \\
\hline $\mathbf{T}_{8}$ & 2159 & 2364 & 43.0 & 48.5 & 14.3 & 17.1 & 100 & 118 \\
\hline $\mathbf{T}_{9}$ & 2180 & 2466 & 44.6 & 49.1 & 14.9 & 17.2 & 104 & 120 \\
\hline $\mathbf{T}_{10}$ & 2730 & 2971 & 55.0 & 62.1 & 18.0 & 21.3 & 131 & 149 \\
\hline $\mathbf{T}_{11}$ & 2992 & 3232 & 61.2 & 69.1 & 20.4 & 23.0 & 142 & 161 \\
\hline SEd & 114 & 115 & 2.2 & 2.5 & 0.7 & 0.7 & 5.4 & 5.2 \\
\hline CD (0.05) & 238 & 240 & 4.6 & 5.2 & 1.5 & 1.6 & 10.7 & 10.9 \\
\hline
\end{tabular}


The percentage increase of $\mathrm{T}_{11}$ over $\mathrm{T}_{1}$ was $32 \%$ and $37 \%$ during kharif2015-16 and 2016-17 respectively. The increased yield in $\mathrm{T}_{11}(30 \times 30 \mathrm{~cm}$ with single seedling and $200 \%$ RDF) might be due to higher number of plants per unit area, which contributed to more number of head per unit area. Moreover may be due to the optimum level of the nutrient elements in soil and their availability to sunflower crop during its all physiological growth and development stages (Ullasa et al., 2014).

\section{Nutrient uptake (Table 5)}

Nutrient uptake pattern of sunflower hybrid has significantly affected by the sowing density and nutrient management levels. $\mathrm{T}_{11}$ (30x30 cm with single seedling with $200 \%$ RDF) significantly recorded higher nutrient uptake during kharif season 2015-16 and 2016-17. As the nutritional status of $T_{11}$ plants was higher, the plants were enable to produce higher biomass and seed yield (Ishfaq et al., 2009). The improved nutritional status of sunflower is mainly attributed to higher DMP and to a lesser extent caused by the increased $\mathrm{N}, \mathrm{P}$ and $\mathrm{K}$ nutrient concentrations.

In conclusion, sowing density of $30 \mathrm{~cm}$ apart row to row and $30 \mathrm{~cm}$ plant to plant distances with single seedling and $200 \%$ RDF provided high productivity in sunflower hybrid $\mathrm{SFH}$ $\mathrm{CO} 2$. Therefore $\mathrm{SFH} \mathrm{CO} 2$ should be planted with a 30x30 cm with single seedling and $200 \%$ RDF in order to exploit its maximum yield potential.

\section{References}

Awasthi, C.P., A.B. Abidi and A.R. Choudhary. 1991. Studies on the nutritional quality of different varieties of chick pea. Indian J. Agri. Res., 25: 21-26.
Beg, A., S.S. Pourdad and S. Alipour. 2007. Row and plant spacing effects on agronomic performance of sunflower in warm and semi-cold area of Iran. Helia, 30(47): 99-104.

Ishfaq, M., A. Ali, A. Khaliq and M. Yaseen, 2009. Allometry, agronomic traits and yield of autumn planted sunflower hybrids under varying row spacing. Pak. J. Agric. Sci., 46: 248- 257.

Mojiri, A. and A. Arzani. 2003. Effects of nitrogen rate and plant density on yield and yield components of sunflower. $J$. Sci. Technol. Agric. Natural Res., 7: 115-125.

Petcu, E., N. Babeanu, O. Popa, E. Partal and S.M. Pricop. 2010. Effect of planting date, plant population and genotype on oil content and fatty acid composition in sunflower. Rom. Agri. Res., 27: 53-57.

Rasool, Faisul-ur, Hasan, I., Badrul Aalum and S.A. Ganie. 2013. Effect of nitrogen, sulphur and farmyard manure on growth dynamics and yield of sunflower (Helianthus annuus L.) under temperate conditions. Scientific Res. Essays, 8(43): 2144-2147.

Singh, S.M and Pacharia, R.K. 1981. Effect of row spacing, nitrogen and phosphorus on sunflower. Indian J. Agron., 52(1): 36-39.

Thimmegowda, M.N., H.V. Nanjapa, and B.K. Ramachandrappa. 2007. Effect of soil solarization and farmyard manure application on weed control and productivity of sunflower (Helianthus annus) bell pepper (Capsicum annum) sequence. Indian J. Agron., 52(3): 204207.

Ullasa, M.Y., Sheshadri, T., Nagaraj, R., Sudheendra Saunshi, Basavaraj Kumbarand Bhavya, M.R. 2014. Effect of Application of Farmyard Manure, Fertilizer Levels and Different Plant Population Levels on Seed Yield, Nutrient Uptake by Sunflower and Final 
Nutrient Status of the Soil. Trends in Biosci., 7(5): 393-395.

Vijayakumar, M. and S. Ramesh, 2005.Effect of crop geometry and nitrogen management on growth analysis and yield of rain-fed sunflower (Helianthus annuus). J. Ecotoxicol. Environ. Monitoring, 15(4): 371-376.

\section{How to cite this article:}

Ravichandran, S., and Srinivasan, K. 2017. Growth and Yield of Kharif Sown Sunflower as Influenced by Plant Density and Nutrient Management. Int.J.Curr.Microbiol.App.Sci. 6(7): 4315-4322. doi: https://doi.org/10.20546/ijcmas.2017.607.449 